\title{
The Relationship between Ritual, Personal Involvement and Travel Intention: A Study of Check-in-Travel on DouYin
}

\author{
Ritong Bian, Mingfang Zhu* \\ School of Shenzhen Tourism Management, Jinan University, Shenzhen, China

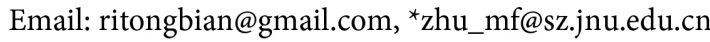

How to cite this paper: Bian, R. T., \& Zhu, M. F. (2020). The Relationship between Ritual, Personal Involvement and Travel Intention: A Study of Check-in-Travel on DouYin. American Journal of Industrial and Business Management, 10, 451-467. https://doi.org/10.4236/ajibm.2020.102030

Received: January 6, 2020

Accepted: February 25, 2020

Published: February 28, 2020

Copyright $\odot 2020$ by author(s) and Scientific Research Publishing Inc. This work is licensed under the Creative Commons Attribution International License (CC BY 4.0).

http://creativecommons.org/licenses/by/4.0/

\begin{abstract}
This study aimed to understand the relationship among ritual, personal involvement and travel intention by examining short video clip users' behavior. Data was gathered from 254 regular users and nonusers of Douyin, which is the most popular Chinese short video platform. Findings show that ritual is positively related to personal involvement, while both ritual and personal involvement are positively related to travel intention. Personal involvement was found to partially mediate the relationship between ritual and travel intention. Implications for destination managers, limitations and future research directions are discussed.
\end{abstract}

\section{Keywords}

Ritual, Personal Involvement, Travel Intention, Social Media, Douyin

\section{Introduction}

Social media and Web 2.0 as technological concepts become more and more familiar with tourists. The increase of tourists prefers to use social media to search for travel information, make a travel plan and share their travel experience. Social media is reshaping our travel form (Kietzmann, Hermkens, McCarthy, \& Silvestre, 2011; Xiang \& Gretzel, 2010). Tiktok was a short video app, which allows users to record 15-second videos and upload them for the whole world to see. More than 500 million people globally use Tiktok monthly. In Tiktok, lots of people participate topics they are interested in by imitating the similar behavior of others.

DouYin which is Tiktok's Chinese version also has a million users monthly, and lots of users like to share their travel experience in Douyin. In Douyin's tra- 
vel topics, people will follow other's videos to specific destinations and show similar consumer behavior during their travel experiences, for example, purchase the same things, pose the similar gesture. This series of consumption processes in travel is been called "Check-in-Travel (CIT)" in China.

Unlike traditional travel plan making, people now tend to seek advice online. Why lots of people are willing to follow Douyin to CIT has caught our attention. The current research investigates people are keen like CIT that people want to receive sacred though the consumption of travel: rituals (Graburn, 1983; Belk, Wallendorf, \& Sherry Jr., 1989). In this study, we hope to use ritual theory to explain why people are passionate about CIT.

Ritual has been studied in the fields of consumption, marketing, and tourism for its huge explanatory power. At present, scholars pay more attention to discovering rituals in consumer life, and there are few empirical studies on rituals to test its effect. In fact, rituals have been studied almost merely with qualitative designs, recently some scholars use experiments to explore the effect of rituals which therefore it "necessary" to draw causal inferences about ritual (Rossano, 2012). Previous research suggests that we may change our thoughts, feelings, and behavior through ritual (Vohs, Wang, \& Gino, 2013).

Although lots of people are willing to follow others for CIT in Douyin, we have little understanding of why people participate in CIT. Some researchers believe that personal involvement may play an important role in CIT based on ritual theory (Vohs et al., 2013; Collins, 2004; Bushnell, 1997). So, we try to understand the relationship of ritual, personal involvement and travel intention by examining the short video clip users' behavior. It is hoped that this study can explain the behavior of tourists with ritual theory in order to provide useful insights for tourism marketing.

\section{Literature Review}

\subsection{Ritual}

As "Little Prince" mentioned, ritual can bring us sacredness: they are what make one day different from other days, one hour from other hours. Indeed, the ritual is initially and traditionally studied in religion and then mythology and psychology started paying attention to ritual (Belk, Wallendof, \& Sherry Jr., 1989; Bell, 1992; Matthews, 2017). The earlier research has focused on the consequences of group ritual with the anthropological, sociological, and psychological domain in which ritual is been seen as sacred and most associated with religion (e.g. Goffman, 1955; Durkheim, 1912; Smith, 1890).

Recently, organizational research (Blake, 2014; Feldman, 1977) and marketing research (Ratcliffe, Baxter, \& Martin, 2019; Rook, 1999) have a tendency to focus on rituals. This is, People's participation in religious group ritual activities has gradually decreased, and the sacred sense brought by religious group rituals is difficult to meet people's needs. People create rituals in their everyday life to seek a sense of sacredness (Belk et al., 1989). Everyone is a consumer, it is easy to create ritual behavior in our consumption. For example, eating Oreo should follow the 
ritual behavior of "twist, lick and soak". Actually, consumption is general and has even been explained as the needed ritual of modern life (Wright \& Snow, 1980). In this period, studies focus on the benefits of ritual for individuals in daily living.

Whether we are as individuals or as members of some larger group, we are unaware of participating in ritual activities in our daily life, at home, work, and study. Additionally, from the small-scale and individuals, such as gift-giving, making tea in the morning, to wider, collectivization, such as annual festive celebrations, rituals are present in our daily experience (Kapitány \& Nielsen, 2015; Sherry Jr., 1983). During this process, typologies of ritual and the causal inferences about rituals have become clear. Ritual in holiday, gift-giving, food and drink all have been verified can enhance consumption, meanwhile can bring more satisfaction for the consumer (Harrison, Reilly, \& Gentry, 2010; Bradford \& Sherry Jr., 2013; Tang, 2017).

\subsection{Ritual in the Travel-Related Literature}

Tourism is an industry with great coverage and involves multiple consumptions, such as accommodation, transportation, food, and drink, etc. Since rituals are used to explain consumer behaviors, it is reasonable to apply ritual in tourism consumption. Ritual in tourism research has been mostly associated with religion travel (Moufahim \& Lichrou, 2019; Robb, 2001). Meanwhile, some scholars notice there exist rituals in tourism consumption. Graburn (2004) regards tourism as a special ritual and proposes the syllogism of tourism: "secular-sacred-secular". It has been verified that during tourism which is a kind of secular consumer behavior, tourists will appear on the way anomalous phenomena that are completely different from the secular (Graburn, 1983). But there is few studies focus on the ritual in tourist consumption, such as go to some certain destination, find the same scene, buy the same food, pose the same gestures and so on.

Different scholars give different definitions of rituals based on their own research perspectives (e.g. anthropology, religion, sociology, psychology), each helps to understand the ritual structure. This leads scholars to suggest that "there is no clear criterion by which cultural anthropologists or other scholars of religion or classics determine that particular type of behavior is or is not an instance of a ritual" (Liénard \& Boyer, 2006).

Accommodating past theoretical research and practical conceptualizations of ritual, we identify three key criteria for ritual: 1) a fixed, episodic sequence of behaviors; 2) symbolic meaning 3) repeat over time (Cohn, 1990; Rook, 1985; Crews \& Boutcher, 1986; Rossano, 2012). First, a fixed and episodic sequence is the most and also easily characterizes ritual. For example, when we celebrate a birthday, everyone follows this sequence: buy a cake-put the candles-make a wish-blow out the candles-eat the cake. Second, by acting this birthday ritual, we are getting the rite of passage which bring the sacredness. Finally, we repeated this behavior years over years.

Based on the definition of the ritual, scholars have put forward different views on the ritual structure. One is to explain the sacredness of rituals from a reli- 
gious perspective (Hobson et al., 2018; Belk et al., 1989). Rook (1985) divides ritual into 4 dimensions through the perspective of consumer behavior. Recently, Collins (2004) based on "Scene" claimed another ritual structure through the perspective of micro-sociology (see Table 1). Each structure is valuable to help us understand rituals in our daily life which include tourism. Though Rook (1985)'s framework of ritual scale is broad, this structure suggests commonalities in ritual activities. It enables us to study ritual behavior from different perspectives, such as tourism perspectives. Thence we use Rook's ritual framework to measure ritual in tourism consumption.

\subsection{Theoretical Framework and Hypotheses}

\subsubsection{Ritual versus Personal Involvement}

Ritual appears in our daily life. Most rituals have a boundary which we can clearly know who is in the ritual and who is not (Collins 2004), this boundary can be seen in community worship or individual birthday party.

Due to the boundaries of rituals, some studies have shown that personal involvement can increase the perception of rituals, while rituals can also increase the involvement of ritual audiences (Dohle et al., 2014; Vohs et al., 2013). Ritual and personal involvement are inseparable. Sherif and Cantril (1947) were the first scholars concerned about personal involvement. Since then, involvement has received extensive attention in marketing and been defined variously. While there is no agreement has been reached on the definition of involvement, it is generally believed that involvement is people's values to something such as an issue, idea or activity (Sherif \& Cantril, 1947). That is, involvement is the connection of people to a particular thing based on their past experiences, interests, and values (Zaichkowsky, 1985).

Table 1. The key concept of ritual.

\begin{tabular}{|c|c|c|}
\hline Authors (date) & What constitutes ritual & Theoretical basis \\
\hline \multirow{4}{*}{ Rook (1985) } & Ritual Artifacts & \multirow{4}{*}{ Consumer behavior } \\
\hline & Ritual Script & \\
\hline & Ritual Performance Roles & \\
\hline & Ritual Audience & \\
\hline \multirow{6}{*}{ Belk et al. (1989) } & Places & \multirow{6}{*}{ Consumer behavior } \\
\hline & Times & \\
\hline & Tangible Things & \\
\hline & Intangible Things & \\
\hline & Persona and Other Beings & \\
\hline & Experience & \\
\hline \multirow{4}{*}{ Collins (2004) } & Group Assembly & \multirow{4}{*}{ Micro-sociology } \\
\hline & Barrier to Outsiders & \\
\hline & Mutual Focus of Attention & \\
\hline & Shared Mood & \\
\hline
\end{tabular}


In tourism, we can find clues that more and more travelers are following others to travel through social media. So, we predict that when the user using social media plan their travel, the video with more ritual behaviors will enhance their interest (which is personal involvement) about travel destinations that this video played.

Hypothesis 1: Ritual is related positively to personal involvement.

Hypothesis 1a: Ritual artifacts is related positively to personal involvement. Hypothesis $1 \mathrm{~b}$ : Ritual script is related positively to personal involvement.

Hypothesis 1c. Ritual performance roles are related positively to personal involvement.

Hypothesis 1d: Ritual audience is related positively to personal involvement.

\subsubsection{Involvement versus Travel Intention}

Involvement is an important component of the travel experience (Gunter \& Gunter, 1980). Involvement is widely used in the field of tourism, the relationship between involvement and sundry tourism issues are been studied. Among them, personal involvement shows a positive effect on satisfaction, loyalty, and travel intention et al. (Huang et al., 2012; Chen \& Tsai, 2008; Lee et al., 2008). So, we predict that when the user using social media plan their travel or see someone travel video, the more they interest (involve) in the more travel intention they have.

Hypothesis 2: Involvement is related positively to travel intention.

\subsubsection{Ritual versus Travel Intention}

As mentioned above, in general, ritual research is still in its infancy, and the bulk of research focuses on the definition and structure of rituals. In terms of the effect of the ritual, most researches concern about the social outcomes of rituals. Recently, the impact of rituals on individuals, especially consumers, has been concerned. From a personal perspective, Ratcliffe et al. (2019) think ritual produces certain outcomes by effect, cognition, and behavior. Ritual enhance consumption has been verified (Vohs et al., 2013). Tourism as a special consumption contains a lot of kinds of consumption, such food, drink, and traffic et al. Watson and Kopachevsky (1994) have argued that "modern tourism is best understood in the context of the commodification process and contemporary consumer culture". In fact, most of the researches in the tourism field are interesting in consumer goods and tourism consumption (Richards, 1996). So, we predict that the ritual travel video comparing to the normal one on social media will enhance user's consumption which is travel intention.

Hypothesis 3: Ritual is related positively to travel intention.

Hypothesis 3a: Ritual artifacts is related positively to travel intention.

Hypothesis $3 \mathrm{~b}$ : Ritual script is related positively to travel intention.

Hypothesis 3c. Ritual performance roles are related positively to travel intention.

Hypothesis 3d: Ritual audience is related positively to travel intention. 


\subsubsection{The Mediating Effect of Personal Involvement}

We predict ritual can enhance travel intention. However, due to differences in personal characteristics, different people may feel the different extent of ritual although they see or do the same ritualized behaviors. Because involvement may play an intermediary role. When we saw something, the different people got different involvement which can influence our later attitudes or even behaviors (Slama \& Tashchian, 1985). When something is consistent with our own hobbies, we would have a high involvement with it. Highly involvement brings us more positive and strong attitudes toward it. These attitudes then may influence our future plans (Sherif, Kelly, Rodgers, Sarup, \& Tittler, 1973). So, we think when the user sees the same ritual video, personal involvement plays a mediating role between ritual and travel intention.

Hypothesis 4: Involvement plays a mediating role between rituals and tourism intentions.

All in all, based on previous literature and practical experience, this study builds a structural relationship between rituals, personal involvement, and travel intentions. At the same time, we divide the ritual into four dimensions according to Rook (1985)'s theory: ritual artifacts, ritual script, ritual performance roles and ritual audience.

\section{Methodology}

\subsection{Sample and Procedure}

In Douyin, there are lots of popular travel videos. Users are willing to go to the same destination to imitate the video's context, such as purchase the same product, pose the same gesture, capture the similar video content. One of them is Xi'an "super-bowl wine". This "super-bowl wine" is consumed in a fixed sequence: 1) the wine is served in a special porcelain bowl; 2) everyone will buy one bowl of wine, after that, they will wait in line and go to the designated place for drinking; 3) in their turn, they will hold the wine above their heads first and then acquiesce to their wishes; 4) they drank the wine in one time and broke the porcelain bowl. We can see the typical ritual behaviors in this tourism consumption based on our definition of ritual before. One of the "super-bowl wine" video clip has been clicked 81.113 million times in Douyin. So, we selected the "super-bowl wine" video to measure ritual.

Responders were chosen based on a convenience sampling method. Travelers who are visiting oct loft (a cultural and creative park in Shenzhen) are our main sampling frame. We chose Shenzhen oct loft as the main research place because oct loft is one of the most popular destination in Shenzhen which attract many people to visit. Before they formally answer the questionnaire, we will first introduce the purpose of this study and show them the video of "super-bowl wine". Respondents were told to feel free to ask us questions during their do this survey. Once they have questions about the questionnaire, an explanation will be given to them which has been told to every investigator in advance. Questionnaires were collected onsite. We returned 312 questionnaires with anonymity 
and confidentiality. We eliminated 58 data missing questionnaires. Finally, we got $254(81.4 \%)$ valid questionnaires.

\subsection{Instrument}

Since the original instruments we used were in English, the respondents were Chinese, we use the backward and forward translation approach to ensure the translation was authentic (Hayashi, Suzuki, \& Sasaki, 1992).

To ensure the accuracy of the instrument, we conducted a pilot study. Fifty students were invited to participate. They were told any questions and confusion in the process of filling out the questionnaire can tell us at any time, such as the wording and clarity of the survey questionnaires.

Ritual experience in tourism is a perceived consumption value for tourists as consumers (Ratcliffe et al., 2019; Belk et al., 1989; Rook 1985). And we use the Perceived Value scale (Voss et al., 2003) to measure the ritual framework. The Perceived Value scale includes two dimensions (Hedonic and utilitarian) with 10 items. This instrument divides consumers' perceived value into hedonic and utilitarian. Marketing and tourism research use this instrument to measure consumer perceived value (Okada, 2005; Oh, Fiore, \& Jeoung, 2007; Hosany \& Witham, 2010; Grohmann, 2009; Alba \& Williams, 2013).

In this study, we use this scale to measure people's attitudes toward ritual. A 5-item short form of the Personal Involvement Inventory (Zaichkowsky, 1985) was utilized to measure personal involvement. This PII scale has been widely used in marketing and tourism research (Sweeney \& Soutar, 2001; Mano \& Oliver, 1993; Sparks, 2007). Travel intention was measured by using the purchase intention scale (Petroshius \& Monroe, 1987), which has one dimension with 3 items. The item was worded as follows: "How likely would you be to take a journey according to the popular video context in the next 12 months?", "How likely would you be to take a travel in different cities based around popular video context in the 12 months?", "How likely would you recommend your friends to take a travel to the city according to around popular video context?". All the scales were measured using Likert type scale from 1 strongly disagree through to 5 strongly agree.

In this study, travel intention was a stand-in for the actual travel plan. There are two reasons. First, there are many factors that influence people making a travel plan, and this would create some sort of response bias. At the same time, in our research, we found that the person who actually travels will affect his actual willingness to travel because of certain travel experience. By asking their travel intention we can reduce questions mentioned before (Wee, Ta, \& Cheok, 1995).

\subsection{Data Analysis}

In this study, we used the Statistical Package for Social Sciences (SPSS) for sample descriptive analysis, reliability and validity analysis, and factor analysis. These analyses are the basis for subsequent correlation regression analysis. Finally, the Process in SPSS was used to run linear regression and intermediary inspection to regulate the relationship between variables. 


\section{Results}

\subsection{Responders' Profile}

Of the 254 completed and valid questionnaires, $60.4 \%$ of the samples were females. Among respondents, most of their ages were under 30 years old (90.2\%). $77.2 \%$ of the samples have a college or university degree. Almost three-fourth of them spent last than 5000 CNY per month. Totally the respondents' profile is basically consistent with Douyin user portraits (Penguin Intelligence, 2018).

\subsection{Internal Consistency and Construct Validity}

First, we use Cronbach's reliability coefficients to exam the internal consistency of each construct. Table 2 shows Cronbach's reliability coefficients of ritual are all over $0.9(\mathrm{RA}=0.907, \mathrm{RS}=0.916, \mathrm{RPR}=0.929, \mathrm{PAU}=0.935)$, Cronbach's reliability coefficients of personal involvement (0.756) and travel intention (0.821) are also above the generally agreed upon lower limit of 0.70 (Hair, Anderson, Tatham, \& Black, 1984). Thus, all the scales have good reliability for subsequent analysis. Table 2 also presents the correlations between ritual, personal involvement, and travel intention. Results showed that ritual artifacts, ritual script, ritual performance roles, ritual audience, and personal involvement were all correlated significantly to the travel intention in a positive direction.

Then, we run the validity analysis to verify the internal structure of the concepts in which EFA (exploratory factor analysis) and KMO (Kaiser-Meyer-Olkin) were conducted (Anderson \& Gerbing, 1988). This item will be eliminated if it meets both of the following conditions: a) its corrected item-total correlation was less than 0.4 ; b) it has large coefficients across multiple dimensions at the same time (Byrne, 2001). Consequently, only one item from ritual artifacts (not fun-fun) were eliminated, other items are all retained. Table 3 reveals the final outcomes. The KMO of the ritual's four dimensions were rung 0.899 to 0.927 . Personal involvement (0.777) and travel intention (0.706) all have good validity which was both higher than the recommended index of 0.60 (Garson, 2001).

Table 2. Correlation and reliabilities of constructs.

\begin{tabular}{lcccccc}
\hline \multicolumn{1}{c}{ Constructs } & 1 & 2 & 3 & 4 & 5 & 6 \\
\hline 1) Ritual artifacts (RA) & {$[0.907]$} & & & & & \\
2) Ritual script (RS) & $0.725^{* *}$ & {$[0.916]$} & & & & \\
3) Ritual performance roles (RPR) & $0.724^{* *}$ & $0.743^{* *}$ & {$[0.929]$} & & \\
4) Ritual audience (RAU) & $0.644^{* *}$ & $0.707^{\star *}$ & $0.789^{* *}$ & {$[0.935]$} & \\
5) Personal involvement (PI) & $0.332^{* *}$ & $0.370^{* *}$ & $0.383^{* *}$ & $0.334^{* *}$ & {$[0.756]$} \\
6) Travel intention (TI) & $0.352^{* *}$ & $0.355^{* *}$ & $0.413^{* *}$ & $0.405^{* *}$ & $0.687^{* *}$ & {$[0.821]$} \\
\hline
\end{tabular}

${ }^{* *} p<0.01$; Reliability coefficients of the respective constructs were on diagonal. 
Table 3. Factor analysis of the measuring instrument.

\begin{tabular}{|c|c|c|c|c|}
\hline Scale items & Factor 1 & adings & KMO & Cumulative $\%$ \\
\hline Ritual artifacts & & & 0.899 & 72.353 \\
\hline 2) Unhelpful-Helpful & 0.848 & & & \\
\hline 3) Not Functional-Functional & 0.844 & & & \\
\hline 5) Impractical-Practical & 0.790 & & & \\
\hline 4) Unnecessary-Necessary & 0.784 & & & \\
\hline 1) Ineffective-Effective & 0.774 & & & \\
\hline 9) Not Thrilling-Thrilling & & 0.861 & & \\
\hline 8) Not Delightful-Delightful & & 0.836 & & \\
\hline 10) Unenjoyable-Enjoyable & & 0.788 & & \\
\hline 7) Dull-Exciting & & 0.744 & & \\
\hline Ritual script & & & 0.900 & 74.220 \\
\hline 7) Dull-Exciting & 0.872 & & & \\
\hline 8) Not Delightful-Delightful & 0.867 & & & \\
\hline 9) Not Thrilling-Thrilling & 0.817 & & & \\
\hline 6) Not Fun-Fun & 0.814 & & & \\
\hline 10) Unenjoyable-Enjoyable & 0.788 & & & \\
\hline 3) Not Functional-Functional & & 0.886 & & \\
\hline 2) Unhelpful-Helpful & & 0.849 & & \\
\hline 1) Ineffective-Effective & & 0.793 & & \\
\hline 5) Impractical-Practical & & 0.789 & & \\
\hline 4) Unnecessary-Necessary & & 0.779 & & \\
\hline Ritual performance roles & & & 0.911 & 76.446 \\
\hline 3) Not Functional-Functional & 0.885 & & & \\
\hline 2) Unhelpful-Helpful & 0.844 & & & \\
\hline 5) Impractical-Practical & 0.837 & & & \\
\hline 4) Unnecessary-Necessary & 0.834 & & & \\
\hline 1) Ineffective-Effective & 0.814 & & & \\
\hline 9) Not Thrilling-Thrilling & & 0.862 & & \\
\hline 8) Not Delightful-Delightful & & 0.835 & & \\
\hline 7) Dull-Exciting & & 0.813 & & \\
\hline 10) Unenjoyable-Enjoyable & & 0.796 & & \\
\hline 6) Not Fun-Fun & & 0.758 & & \\
\hline Ritual audience & & & 0.927 & 76.469 \\
\hline 3) Not Functional-Functional & 0.844 & & & \\
\hline 5) Impractical-Practical & 0.834 & & & \\
\hline 4) Unnecessary-Necessary & 0.820 & & & \\
\hline
\end{tabular}




\section{Continued}

\begin{tabular}{|c|c|c|c|c|}
\hline 1) Ineffective-Effective & 0.814 & & & \\
\hline 2) Unhelpful-Helpful & 0.803 & & & \\
\hline 9) Not Thrilling-Thrilling & & 0.856 & & \\
\hline 7) Dull-Exciting & & 0.829 & & \\
\hline 8) Not Delightful-Delightful & & 0.828 & & \\
\hline 10) Unenjoyable-Enjoyable & & 0.797 & & \\
\hline 6) Not Fun-Fun & & 0.744 & & \\
\hline Personal involvement & & & 0.777 & 52.677 \\
\hline 2) Know others' comments & 0.840 & & & \\
\hline 1) Learn more information & 0.792 & & & \\
\hline 3) Compare different destination & 0.778 & & & \\
\hline 5) Have my favorite destinations & 0.706 & & & \\
\hline 4) Hot Cities have Significant Differences & 0.443 & & & \\
\hline Travel intention & & & 0.706 & 73.613 \\
\hline 2) Travel to different destinations based on videos & 0.885 & & & \\
\hline 3) Recommends to friends & 0.861 & & & \\
\hline 1) Would you like to travel following this video & 0.827 & & & \\
\hline
\end{tabular}

\subsection{Evaluation of the Hypothesized Relationship}

\subsubsection{Hypothesis Testing of Relationships}

To test the hypothetical relationships, linear regression was conducted by taking the maximum likelihood estimation method. Table 4 shows the results of the hypothesis. As hypothesized, ritual had a positive and significant effect on personal involvement $(\beta=0.399, \mathrm{t}$ value $=6.884, p=0.000)$. Hypothesis 1 was supported. Additionally, ritual artifacts, ritual script, ritual performance roles, and the ritual audience had a positive and significant effect on personal involvement. Hypothesis 1a, 1b, 1c, 1d were supported. Hypothesis 2 predicted that personal involvement was positively related to travel intention which is also been supported $(\beta=0.687, \mathrm{t}$ value $=15.008, p=0.000)$. Hypothesis 3 proposed that ritual can enhance our travel intention. Data analysis results show that this hypothesis is verified $(\beta=0.430, \mathrm{t}$ value $=7.537, p=0.000)$. Also, ritual artifacts, ritual script, ritual performance roles, and the ritual audience had a positive and significant effect on travel intention. Hypothesis $3 a, 3 b, 3 c$, $3 d$ were supported.

Ritual was hypothesized to affect travel intention through personal involvement. The direct, indirect and total effects of ritual on travel intention were 0.2211, 0.2916 and $0.5127(0.2211+0.2916)$. Personal involvement was an important mediator variable to travel intention due to the indirect effect (0.2916) are higher than the direct effect (0.2211). However, there is still a significant correlation between rituals and travel intentions which means that personal involvement is partial rather than full mediation (Hair et al., 2006). In this part, we also tested the mediating effect of personal involvement between ritual artifacts, ritual script, ritual performance roles, ritual audience, and travel intention. 


\subsubsection{Mediating Effect}

The results of the mediation analysis are illustrated in Table 5. Ritual performance roles $(0.4291)$ and ritual audience $(0.4081)$ have more potential to predict travel intentions than ritual artifacts (0.3951) and ritual script (0.3855). Based on the above evidence, Hypothesis 4 was partially supported.

Table 4. Results of hypothesis testing.

\begin{tabular}{|c|c|c|c|c|}
\hline Hypothesis & Effects & Standardized Regression Weight & $\mathrm{t}$ value & Results \\
\hline $\mathrm{H} 1$ & $\begin{array}{l}\text { Ritual } \\
\rightarrow \text { Personal involvement }\end{array}$ & 0.399 & $6.884^{\star * *}$ & Accept \\
\hline H1a & $\begin{array}{c}\text { Ritual artifacts } \\
\rightarrow \text { Personal involvement }\end{array}$ & 0.332 & $5.582^{* * *}$ & Accep \\
\hline $\mathrm{H} 1 \mathrm{~b}$ & $\begin{array}{c}\text { Ritual script } \\
\rightarrow \text { Personal involvement }\end{array}$ & 0.370 & $6.303^{\star * *}$ & Accep \\
\hline $\mathrm{H} 1 \mathrm{c}$ & $\begin{array}{l}\text { Ritual performance roles } \\
\rightarrow \text { Personal involvement }\end{array}$ & 0.383 & $6.573^{* * *}$ & Accep \\
\hline H1d & $\begin{array}{c}\quad \text { Ritual audience } \\
\rightarrow \text { Personal involvement }\end{array}$ & 0.334 & $5.628^{* * *}$ & Accep \\
\hline $\mathrm{H} 2$ & $\begin{array}{l}\text { Personal involvement } \\
\quad \rightarrow \text { Travel intention }\end{array}$ & 0.687 & $15.008^{* * *}$ & Accep \\
\hline H3 & $\begin{array}{c}\text { Ritual } \\
\rightarrow \text { Travel intention }\end{array}$ & 0.430 & $7.537^{\star * *}$ & Accep \\
\hline $\mathrm{H} 3 \mathrm{a}$ & $\begin{array}{l}\text { Ritual artifacts } \\
\rightarrow \text { Travel intention }\end{array}$ & 0.352 & $5.963^{\star * *}$ & Accep \\
\hline $\mathrm{H} 3 \mathrm{~b}$ & $\begin{array}{l}\text { Ritual script } \\
\rightarrow \text { Travel intention }\end{array}$ & 0.355 & $6.017^{* * *}$ & Accep \\
\hline $\mathrm{H} 3 \mathrm{c}$ & $\begin{array}{c}\text { Ritual performance roles } \\
\quad \rightarrow \text { Travel intention }\end{array}$ & 0.413 & $7.191^{\star * *}$ & Accep \\
\hline $\mathrm{H} 3 \mathrm{~d}$ & $\begin{array}{l}\text { Ritual audience } \\
\rightarrow \text { Travel intention }\end{array}$ & 0.405 & $7.032^{\star * *}$ & Accep \\
\hline
\end{tabular}

${ }^{* * *} p<0.000$.

Table 5. Results of mediation analysis.

\begin{tabular}{ccccccc}
\hline Relationships & Total effects & Direct effects & Indirect effects & LLCI & ULCI & Results \\
\hline RA-TI & 0.3951 & $0.1562^{* *}$ & & 0.0504 & 0.2621 & Accept \\
RA-PI-TI & & & $0.2389^{* * *}$ & 0.1525 & 0.3294 & Accept \\
RS-TI & 0.3855 & $0.1271^{*}$ & & 0.0225 & 0.2317 & Accept \\
RS-PI-TI & & & $0.2584^{* * *}$ & 0.1721 & 0.3463 & Accept \\
RPR-TI & 0.4291 & $0.1825^{* *}$ & & 0.0834 & 0.2816 & Accept \\
PPR-PI-TI & & & $0.2466^{* * *}$ & 0.1643 & 0.3353 & Accept \\
RAU-TI & 0.4081 & $0.1990^{* * *}$ & & 0.1057 & 0.2924 & Accept \\
PAU-PI-TI & & & $0.2091^{* * *}$ & 0.1327 & 0.2960 & Accept \\
Ritual-TI & 0.5127 & $0.2211^{* * *}$ & & 0.1065 & 0.3356 & Accept \\
Ritual-PI-TI & & & $0.2916^{* * *}$ & 0.2029 & 0.3884 & Accept \\
\hline
\end{tabular}

${ }^{*} p<0.05 ;{ }^{* *} p<0.01 ;{ }^{* *} p<0.001 ; \mathrm{LLCI}=$ lower limit confidence interval; $\mathrm{ULCI}=$ upper limit confidence interval. 


\subsection{Summary of Result}

As tested before, the four dimensions of the ritual have a positive correlation with personal involvement and travel intention, and personal involvement can positively predict travel intention, which indicates that hypothesis 1 , hypothesis 2 , hypothesis 3 has all been verified. At the same time, we verified that personal involvement plays a part of the mediating role between ritual and travel intentions, which indicates that hypothesis 4 has been verified.

\section{Discussion}

The earliest studies of rituals were related to religion (Durkheim, 1912; Deflem, 1991). Since ritual was been found appear in our daily consumer life, the impact of the ritual on people's daily consumption is studied (Vohs et al., 2013; Darmody \& Bonsu, 2007; Marshall, 2005; Tetreault \& Robert III, 1990). However, as far as we know, the rituals in tourism have not yet received much attention. To expand the ritual research area, the current study first clarified the definition of ritual in tourism, then examined the relationship among ritual, personal involvement and travel intention based on previous research results.

In this study, we divide the ritual into four dimensions: Ritual artifacts (RA), Ritual script (RS), Ritual performance roles (RPR) and Ritual audience (RAU) base on Rook (1985)'s research. Our research results show that tourists can perceive all the four dimensions of rituals in tourism activities.

As expected, the ritual's four dimensions all had a powerful and positive relationship with personal involvement. At the same time, we found among them ritual script (RS) and ritual performance roles (RPR) were more powerful for investigating the relationship between ritual and personal involvement. When people see others' travel experiences in Douyin, the ritual can increase their involvement. That is people are more likely to find more information about destination if they feel more ritual in others' travel experiences. Especially ritual performance roles (RPR) and ritual audience (RAU) can increase tourist involvement more effectively.

Consistent with other scholar's research results, the relationship between personal involvement and travel intentions in this study has also been verified (Yen \& Teng, 2015; Ferns \& Walls, 2012; Huang et al., 2010). That's means that tourist who is involved in the ritual are more likely to plan their trip. The findings also indicate rituals can predict not only personal involvement but also travel intentions. Further, compared with ritual artifacts and ritual scripts, ritual audiences and ritual roles perceived by people are more possible to plan their travel by watching the same travel video.

In summary, we found that ritual and personal involvement are related to travel intention. What's more, ritual enhances travel intention through personal involvement. In other words, if a tourist has highly ritual-perception, he or she is more involved in the travel destination, which is more possible to turn to travel intention finally. At the same time, the mediation effect results expose that the 
direct effect of ritual on travel intention is less than the indirect effect of ritual on travel intention through personal involvement. This suggests that tourists who perceived ritual and involved in tourism have more motivation to travel than those who only perceived ritual. That is, the effect of ritual on travel intention is enhanced via personal involvement.

\section{Conclusion}

There are several theoretical implications of this study. First, the division of ritual dimensions (ritual artifacts, ritual script, ritual performance roles, and ritual audience) in tourism activities have been verified in this study. In subsequent studies, scholars can analyze ritual behavior in tourism according to this dimension. Second, the relationship model between ritual, personal involvement, and travel intentions was verified, which enriches ritual theoretical research. By reason of personal involvement has played a part in mediation, it implies that there may be some mediators that could be included in the current model to better predict travel intention. Finally, we found some follow-up behaviors in tourism can be explained by ritual theory. In this study, we can find that part of the reason why people are willing to follow social media to travel today is that people feel a sense of ritual in the travel videos shared by others. This perception of ritual increased their willingness to travel.

Based on the findings of the study, a number of practical implications can be derived. Ritual is a useful tool to enhance personal involvement and travel intention. In tourism marketing, tourism companies can create more ritual activities based on the ritual structure in this research and use social media to spread. Moreover, the positive effect of personal involvement on travel intention implies that tourism companies should provide more convenient ways for tourists to understand relevant tourism information to increase tourism involvement. For example, adding vacation destination product links to related tourism videos.

Although the results of the current study confirmed that ritual may enhance personal involvement and travel intention in the context of tourism, there are a number of limitations. First, the sample of our research is limited to Shenzhen oct loft, and the diversity of the sample needs to be further strengthened. Second, the questionnaire recycle time is almost three months. The time period is a little short. A longitudinal design in future studies would be more powerful in identifying relationships among the constructs of the current study. Third, this paper uses the perceived value scale to measure ritual, and subsequent research can continuously clarify the ritual behavior in tourism and generate a tourism ritual scale. Additionally, with the development of ritual theory, there may be more reasonable ritual structures suitable for explaining tourism behavior.

\section{Acknowledgements}

The work was supported by the Major Graduate Research Support Projects in 2019 of the China Ministry of Culture and Tourism [WLRCY2019-071], Guangdong Planning Project of Philosophy and Social Sciences [GD18XGL51]. 


\section{Conflicts of Interest}

The authors declare no conflicts of interest regarding the publication of this paper.

\section{References}

Alba, J. W., \& Williams, E. F. (2013). Pleasure Principles: A Review of Research on Hedonic Consumption. Journal of Consumer Psychology, 23, 2-18. https://doi.org/10.1016/j.jcps.2012.07.003

Anderson, J. C., \& Gerbing, D. W. (1988). Structural Equation Modeling in Practice: A Review and Recommended Two-Step Approach. Psychological Bulletin, 103, 411-423. https://doi.org/10.1037/0033-2909.103.3.411

Belk, R. W., Wallendorf, M., \& Sherry Jr., J. F. (1989). The Sacred and the Profane in Consumer Behavior: Theodicy on the Odyssey. Journal of Consumer Research, 16, 1-38. https://doi.org/10.1086/209191

Bell, C. (1992). Ritual Theory, Ritual Practice. Oxford University Press, Oxford.

Blake, J. (2014). Identity on the March: Participating in Contentious Rituals in Northern Ireland. APSA 2014 Annual Meeting Paper.

Bradford, T. W., \& Sherry Jr., J. F. (2013). Orchestrating Rituals through Retailers: An Examination of Gift Registry. Journal of Retailing, 89, 158-175. https://doi.org/10.1016/j.jretai.2013.01.005

Bushnell, M. (1997). Small School Ritual and Parent Involvement. The Urban Review, 29, 283-295. https://doi.org/10.1023/A:1024600816995

Byrne, B. M. (2001). Structural Equation Modeling with AMOS, EQS, and LISREL: Comparative Approaches to Testing for the Factorial Validity of a Measuring Instrument. International Journal of Testing, 1, 55-86. https://doi.org/10.1207/S15327574IJT0101_4

Chen, C. F., \& Tsai, M. H. (2008). Perceived Value, Satisfaction, and Loyalty of TV Travel Product Shopping: Involvement as a Moderator. Tourism Management, 29, 1166-1171. https://doi.org/10.1016/j.tourman.2008.02.019

Cohn, P. J. (1990). Preperformance Routines in Sport: Theoretical Support and Practical Applications. The Sport Psychologist, 4, 301-312. https://doi.org/10.1123/tsp.4.3.301

Collins, R. (2004). Interaction Ritual Chains. Princeton, NJ: Princeton University Press. https://doi.org/10.1515/9781400851744

Crews, D. J., \& Boutcher, S. H. (1986). An Exploratory Observational Behavior Analysis of Professional Golfers during Competition. Journal of Sport Behavior, 9, 51-58.

Darmody, A., \& Bonsu, S. K. (2007). Ambivalence in Death Ritual Consumption. In S. Borghini, M. A. McGrath, \& C. Otnes (Eds.), European Advances in Consumer Research (Vol. 8, pp. 51-52). Duluth: Association for Consumer Research.

Deflem, M. (1991). Ritual, Anti-Structure, and Religion: A Discussion of Victor Turner's Processual Symbolic Analysis. Journal for the Scientific Study of Religion, 30, 1-25. https://doi.org/10.2307/1387146

Dohle, S., Rall, S., \& Siegrist, M. (2014). I Cooked It Myself: Preparing Food Increases Liking and Consumption. Food Quality and Preference, 33, 14-16.

https://doi.org/10.1016/j.foodqual.2013.11.001

Durkheim, E. (1912). The Elementary Forms of the Religious Life. London: Allen \& Unwin.

Feldman, D. C. (1977). The Role of Initiation Activities in Socialization. Human Relations, 30, 977-990. https://doi.org/10.1177/001872677703001102 
Ferns, B. H., \& Walls, A. (2012). Enduring Travel Involvement, Destination Brand Equity, and Travelers' Visit Intentions: A Structural Model Analysis. Journal of Destination Marketing \& Management, 1, 27-35. https://doi.org/10.1016/j.jdmm.2012.07.002

Garson, D. (2001). PA 765 Statnotes: An Online Textbook (Vol. 2001). http://www2.chass.ncsu.edu/garson/pa765/statnote.htm

Goffman, E. (1955). On Face-Work: An Analysis of Ritual Elements in Social Interaction. Psychiatry, 18, 213-231. https://doi.org/10.1080/00332747.1955.11023008

Graburn, N. H. (1983). The Anthropology of Tourism. Annals of Tourism Research, 10, 9-33. https://doi.org/10.1016/0160-7383(83)90113-5

Graburn, N. H. (2004). Secular Ritual: A General Theory of Tourism. In S. B. Gmelch (Ed.), Tourists and Tourism: A Reader (pp. 23-34). Long Grove, IL: Waveland.

Grohmann, B. (2009). Gender Dimensions of Brand Personality. Journal of Marketing Research, 46, 105-119. https://doi.org/10.1509/jmkr.46.1.105

Gunter, B. G., \& Gunter, N. C. (1980). Leisure Styles: A Conceptual Framework for Modem Leisure. Sociological Quarterly, 21, 361-374. https://doi.org/10.1111/j.1533-8525.1980.tb00618.x

Hair, J. F., Anderson, R. E., Tatham, R. L., \& Black, W. C. (1984). Multivariate Data Analysis with Readings, 1995. Tulsa, OK: Petroleum Publishing.

Hair, J. F., Black, W. C., Babin, B. J., Anderson, R. E., \& Tatham, R. L. (2006). Multivariate Data Analysis. Upper Saddle River, NJ: Pearson Prentice Hall.

Harrison, R., Reilly, T., \& Gentry, J. (2010). Black Friday: A Video-Ethnography of an Experiential Shopping Event. In ACR North American Advances.

Hayashi, C., Suzuki, T., \& Sasaki, M. (1992). Data Analysis for Comparative Social Research: International Perspectives. Amsterdam: Elsevier Science Publishers.

Hobson, N. M., Schroeder, J., Risen, J. L., Xygalatas, D., \& Inzlicht, M. (2018). The Psychology of Rituals: An Integrative Review and Process-Based Framework. Personality and Social Psychology Review, 22, 260-284. https://doi.org/10.1177/1088868317734944

Hosany, S., \& Witham, M. (2010). Dimensions of Cruisers' Experiences, Satisfaction, and Intention to Recommend. Journal of Travel Research, 49, 351-364. https://doi.org/10.1177/0047287509346859

Huang, C. Y., Chou, C. J., \& Lin, P. C. (2010). Involvement Theory in Constructing Bloggers' Intention to Purchase Travel Products. Tourism Management, 31, 513-526. https://doi.org/10.1016/j.tourman.2009.06.003

Huang, Y. C., Backman, S. J., \& Backman, K. F. (2012). Exploring the Impacts of Involvement and Flow Experiences in Second Life on People's Travel Intentions. Journal of Hospitality and Tourism Technology, 3, 4-23. https://doi.org/10.1108/17579881211206507

Kapitány, R., \& Nielsen, M. (2015). Adopting the Ritual Stance: The Role of Opacity and Context in Ritual and Everyday Actions. Cognition, 145, 13-29. https://doi.org/10.1016/j.cognition.2015.08.002

Kietzmann, J. H., Hermkens, K., McCarthy, I. P., \& Silvestre, B. S. (2011). Social Media? Get Serious! Understanding the Functional Building Blocks of Social Media. Business Horizons, 54, 241-251. https://doi.org/10.1016/j.bushor.2011.01.005

Lee, S., Scott, D., \& Kim, H. (2008). Celebrity Fan Involvement and Destination Perceptions. Annals of Tourism Research, 35, 809-832. https://doi.org/10.1016/j.annals.2008.06.003

Liénard, P., \& Boyer, P. (2006). Whence Collective Rituals? A Cultural Selection Model of Ritualized Behavior. American Anthropologist, 108, 814-827.

https://doi.org/10.1525/aa.2006.108.4.814 
Mano, H., \& Oliver, R. L. (1993). Assessing the Dimensionality and Structure of the Consumption Experience: Evaluation, Feeling, and Satisfaction. Journal of Consumer Research, 20, 451-466. https://doi.org/10.1086/209361

Marshall, D. (2005). Food as Ritual, Routine or Convention. Consumption Markets \& Culture, 8, 69-85. https://doi.org/10.1080/10253860500069042

Matthews, T. (2017). Sacred Service: The Use of "Sacred Theory" in Service Design. Journal of Design, Business \& Society, 3, 67-97. https://doi.org/10.1386/dbs.3.1.67_1

Moufahim, M., \& Lichrou, M. (2019). Pilgrimage, Consumption, and Rituals: Spiritual Authenticity in a Shia Muslim Pilgrimage. Tourism Management, 70, 322-332. https://doi.org/10.1016/j.tourman.2018.08.023

Oh, H., Fiore, A. M., \& Jeoung, M. (2007). Measuring Experience Economy Concepts: Tourism Applications. Journal of Travel Research, 46, 119-132. https://doi.org/10.1177/0047287507304039

Okada, E. M. (2005). Justification Effects on Consumer Choice of Hedonic and Utilitarian Goods. Journal of Marketing Research, 42, 43-53. https://doi.org/10.1509/jmkr.42.1.43.56889

Penguin Intelligence (2018). Users Research Report of Douyin \& Kuaishou. https://tech.qq.com/a/20180409/002763.htm

Petroshius, S. M., \& Monroe, K. B. (1987). Effect of Product-Line Pricing Characteristics on Product Evaluations. Journal of Consumer Research, 13, 511-519. https://doi.org/10.1086/209084

Ratcliffe, E., Baxter, W. L., \& Martin, N. (2019). Consumption Rituals Relating to Food and Drink: A Review and Research Agenda. Appetite, 134, 86-93. https://doi.org/10.1016/j.appet.2018.12.021

Richards, G. (1996). Production and Consumption of European Cultural Tourism. Annals of Tourism Research, 23, 261-283. https://doi.org/10.1016/0160-7383(95)00063-1

Robb, J. (2001). Island Identities: Ritual, Travel and the Creation of Difference in Neolithic Malta. European Journal of Archaeology, 4, 175-202. https://doi.org/10.1177/146195710100400202

Rook, D. W. (1985). The Ritual Dimension of Consumer Behavior. Journal of Consumer Research, 12, 251-264. https://doi.org/10.1086/208514

Rook, D. W., \& Levy, S. J. (1999). Psychosocial Themes in Consumer Grooming Rituals. Brands, Consumers, Symbols and Research: Sidney J Levy on Marketing, 375, 21-43. https://doi.org/10.4135/9781452231372.n38

Rossano, M. J. (2012). The Essential Role of Ritual in the Transmission and Reinforcement of Social Norms. Psychological Bulletin, 138, 529-549. https://doi.org/10.1037/a0027038

Sherif, C. W., Kelly, M., Rodgers Jr., H. L., Sarup, G., \& Tittler, B. I. (1973). Personal Involvement, Social Judgment, and Action. Journal of Personality and Social Psychology, 27, 311-328. https://doi.org/10.1037/h0034948

Sherif, M., \& Cantril, H. (1947). The Psychology of Ego-Involvement: Social Attitudes and Identifications. New York: Wiley. https://doi.org/10.1037/10840-000

Sherry Jr., J. F. (1983). Gift Giving in Anthropological Perspective. Journal of Consumer Research, 10, 157-168. https://doi.org/10.1086/208956

Slama, M. E., \& Tashchian, A. (1985). Selected Socioeconomic and Demographic Characteristics Associated with Purchasing Involvement. Journal of Marketing, 49, 72-82. https://doi.org/10.1177/002224298504900107

Smith, R. (1890). The Religion of the Semites. The Jewish Quarterly Review, 2, 178-182. https://doi.org/10.2307/1450097 
Sparks, B. (2007). Planning a Wine Tourism Vacation? Factors That Help to Predict Tourist Behavioral Intentions. Tourism Management, 28, 1180-1192. https://doi.org/10.1016/j.tourman.2006.11.003

Sweeney, J. C., \& Soutar, G. N. (2001). Consumer Perceived Value: The Development of a Multiple-Item Scale. Journal of Retailing, 77, 203-220. https://doi.org/10.1016/S0022-4359(01)00041-0

Tang, T. (2017). Tang Ting, The Impact of Ritual Perception on Evaluation of Gifts in Gift-Giving. Master's Thesis, Changsha: Hunan University.

Tetreault, M. A. S., \& Robert III, E. K. (1990). Ritual, Ritualized Behavior, and Habit: Refinements and Extensions of the Consumption Ritual Construct. In ACR North American Advances.

Vohs, K. D., Wang, Y., Gino, F., \& Norton, M. I. (2013). Rituals Enhance Consumption. Psychological Science, 24, 1714-1721. https://doi.org/10.1177/0956797613478949

Voss, K. E., Spangenberg, E. R., \& Grohmann, B. (2003). Measuring the Hedonic and Utilitarian Dimensions of Consumer Attitude. Journal of Marketing Research, 40, 310-320. https://doi.org/10.1509/jmkr.40.3.310.19238

Watson, G. L., \& Kopachevsky, J. P. (1994). Interpretations of Tourism as Commodity. Annals of Tourism Research, 21, 643-660. https://doi.org/10.1016/0160-7383(94)90125-2

Wee, C. H., Ta, S. J., \& Cheok, K. H. (1995). Non-Price Determinants of Intention to Purchase Counterfeit Goods: An Exploratory Study. International Marketing Review, 12, 19-46. https://doi.org/10.1108/02651339510102949

Wright, D. E., \& Snow, R. E. (1980). Consumption as Ritual in the High Technology Society. Rituals and Ceremonies in Popular Culture, 338.

Xiang, Z., \& Gretzel, U. (2010). Role of Social Media in Online Travel Information Search. Tourism Management, 31, 179-188. https://doi.org/10.1016/j.tourman.2009.02.016

Yen, C. H., \& Teng, H. Y. (2015). Celebrity Involvement, Perceived Value, and Behavioral Intentions in Popular Media-Induced Tourism. Journal of Hospitality \& Tourism Research, 39, 225-244. https://doi.org/10.1177/1096348012471382

Zaichkowsky, J. L. (1985). Measuring the Involvement Construct. Journal of Consumer Research, 12, 341-352. https://doi.org/10.1086/208520 